\title{
Education and Socialization in Ghana
}

\author{
George J. Sefa Dei \\ Ontario Institute for Studies in Education, University of Toronto, Toronto, Canada. \\ Email: gdei@oise.utoronto.ca \\ Received February $10^{\text {th }}, 2011$; revised April $10^{\text {th }}, 2011$; accepted May $16^{\text {th }}, 2011$.
}

\begin{abstract}
Africa has always been an important source of rich information for knowledge production. There has always been a curiosity about Africa that has served different imaginations and interests. But how do we learn and teach about Africa in ways that are informed by an appreciation of African peoples' rich cultural knowledges, complexity and historic resistance of local peoples to carve out their own futures and dreams? I would maintain that knowing about education and socialization offer some important directions in this search for knowledge. Traditional African education has utilized a variety of instructional and pedagogic methods as well as guides and resources to educate youth. Education in African communities has happened in multiple sites, formal and non-formal. Just as West African education can benefit from a study of educational delivery in other contexts, I would argue that a study of important aspects of West African formal and non formal education and socialization of young learners may offer significant lessons for educating youth in other societies. There is intellectual relevance in asking such questions as: what and how do students in West African learn? What activities, stories do students experience in their education that can be incorporated into the curriculum to enrich educating students from diverse backgrounds in other contexts? What is the nature of the environment in which students learn in West Africa?
\end{abstract}

Keywords: African Education, Development, Cultural Knowledge, Ghanaian Learners

\section{Introduction}

Using West African case material this paper explores the place of local cultural/Indigenous knowledges in African schoolling and education. The focus is on the relevance of teachings of such Indigenous knowledge systems as they enhance the education of the contemporary learner. Africa has always been an important source of rich information for knowledge production. There has always been a curiosity about Africa that has served different imaginations and interests. But how do we learn and teach about Africa in ways that are informed by an appreciation of African peoples' rich cultural knowledges, complexity and historic resistance of local peoples to carve out their own futures and dreams? I would maintain that knowing about education and socialization offer some important directions in this search for knowledge. Traditional African education has utilized a variety of instructional and pedagogic methods as well as guides and resources to educate youth. Education in African communities has happened in multiple sites, formal and non-formal. Just as West African education can benefit from a study of educational delivery in other contexts, I would argue that a study of important aspects of West African formal and non formal education and socialization of young learners may offer significant lessons for educating youth in other societies. There is intellectual relevance in asking such questions as: What and how do students in West African learn? What activities, stories do students experience in their education that can be incorporated into the curriculum to enrich educating students from diverse backgrounds in other contexts? What is the nature of the environment in which students learn in West Africa?

Informal sites and systems of education have contributed tremendously to the education of the African child, not much attention has been paid to the sites of traditional instruction and pedagogies contained in local cultural resource base of West African peoples. One example is the use of local cultural knowings embed in proverbs, folktales and songs (see Boateng, 1990; Bascom, 1965; Opoku, 1977; Yankah, 1989, 1995 among many others). How then do we come to re-conceptualize schooling and education to bring about change in [West] African contexts? Schooling has tended to focus heavily on the formal instruction mode, with learners simply acquiring basic knowledge, which is not necessarily relevant or applicable to solving the local problems and challenges of everyday living. Presenting education broadly, beyond formal schooling, allows us to rethink ways knowledge can be utilized to address contemporary problems (see also Abdi \& Cleghorn, 2005). Educators can utilize knowledge from several sources to educate. Such knowledge exists in West African texts, songs, histories as well as local customary practices and traditions that have helped sustain communities for centuries. The local cultural knowledge of West Africa should be looked at as a viable source of education for contemporary learners.

Rethinking schooling and education in Africa goes beyond the requirements and objectives of formal education. This is a project about development in general. In his critique of the "myth of development", [as in unfulfilled promises] Tucker (1999) notes that "the model of development now widely pursued is part of the problem rather than the solution" and that this Western ideology of development "distorts our imagination, limits our vision, [obscuring] us to the alternatives that human initiative is capable of imagining and implementing” (p. 1). The same can be said of contemporary education. Contemporary education in West Africa is mired in the reproduction of colonial hierarchies of power and knowledge and is struggling for local relevance. Such education addresses the needs of a global market economy without addressing what is needed for local 
contexts. In order to imagine new possibilities, West African schooling and education must deconstruct the myth of development using local and Indigenous cultural knowledge. Today, Indigenous and local communities continue to struggle to create an education that paves the way for new cultural, economic and political imaginings of development.

Much of on-going intellectual discussion on "education" is located in the dominant paradigms of Western thinking. Alternative ideas and counter theoretical perspectives of education are not always encouraged and struggle to disentangle from the dominance of the Eurocentric paradigm. We must begin by developing Indigenous, non-Western concepts and categories for understanding African societies. This requires that we pay particular attention to the production and the social organization of knowledge in West Africa, and particularly, to cultural dimensions of schooling, education and development. The question of who controls the "education" discourse or agenda and why is significant, especially when we begin to interrogate issues of power and resistance under local initiatives.

As also noted in Dei (2011a), I define "Indigenous" as local cultural knowledge that draws on the interconnections of society, culture and nature. Indigenous is about a relation to land as a place of long-term, unbroken residence while local cultural knowledge relates to how local peoples make sense of their society-culture and nature interface (see also Roberts et al. 2004; Purcell, 1998). The concept of "Indigenous" is NOT to be thought of in relation to Western knowledge. The concept of "Indigenous" simply alludes to the power relations within which local peoples struggle to define and assert their own representations of history, identity, culture and place in the face of Western hegemonic ideologies. Implicit in the terminology of "Indigenous" is a recognition of some philosophical, conceptual and methodological differences between Western and non-Western knowledge systems. These differences are not absolutes but a matter of degree. The difference is seen more in terms of cultural logics and epistemologies, i.e., differences in the making of sense as always dependent on context, history, politics and place (see also Agrawal, 1995; Semali \& Kincheloe, 1999; Dei, Hall, \& Rosenberg, 2000; Battiste \& Henderson, 2000; Dei, 2011b).

A critical discussion of Indigenous knowledge must also focus on the construction of knowledge, access to knowledge, the transfer of knowledge, and the application of such knowledge as part of multiple ways of knowing. A major contemporary challenge we face in discussing such knowledge in the academy is to address the trivialization and devaluation of local knowledge. For example, one encounters even some local Indigenous scholars so entrenched in Eurocentric ideas that they devalue such Indigenous knowledge systems through colonial mimicry. There is also the fact that local Indigenous Western-educated scholars have not been schooled in the socio-cultural and philosophical paradigms of their own communities. There is a need for increased Indigenous consciousness in order to cultivate such local knowledge and contribute to the search for local solutions to local problems. No Indigenous cultural knowledge is alien to its particular socio-cultural and political milieu (see Yankah, 2004). Local cultural knowledge holds the spiritual and cultural foundations upon which the survival of local communities rest.

Indigenous knowledge is knowledge that arises from long- term occupancy of a place and coming to understand the interrelations of history, ancestry, society, culture and nature. It is knowledge that helps the local residents of a place through time immemorial make sense of their social and natural worlds. It is knowledge accumulated in local traditions, cultural histories and practices and can be learned from a study of local folktales, proverbs, songs, fables and tales, local plant pharmacology, plant herbal medicinal practices, local classification of soils and vegetation, court practices and traditional cultural artifacts among many other things.

Within communities there are certain key symbols of culture "which by their redundancies, pervasiveness and importance can be seen as capturing and expressing a society's focal cultural concern” (see Limon, 1991: p. 118; Ortner, 1973). Every community chooses certain values, norms and social customs to highlight in order to demonstrate the issues of pri- mary [not exclusive] concern. Thus, acceding to the require- ments of "community and social responsibility" may be re- warded in one society as opposed to the affirmation of "indi- viduality and individual rights” (see Dei, 1993). In other words, within different knowledge systems and/or world views there are particular understandings of the relationships between soci- ety, culture and nature that can be privileged and rewarded. Such understanding may form a legitimate basis of distinguish- ing between different world views.

The interactions of different cultures and cultural knowledge have always been part of human reality and existence. Such understanding ought to be distinguished from an uncritical postmodernist claim that what emerges from an articulation of two or more disparate elements is often a new distinct from such that the former disparate elements [form] often lose their character, logics and identities. In a global context when dominant knowledge forms usually appropriate other knowledge and claim universality in their interpretations of society, there is a politics of reclaiming the Indigenous and local identities. This reclamation has a purpose in en-masking the process through which Western science knowledge, for example, becomes hegemonic ways of knowing by masquerading as universal knowledge.

Hence, it is crucial to separate the politics and efficacy of disrupting/interrupting binary thoughts and the [en]coding of cultural differences from a positive (solution-oriented) affirmation of important differences that distinguish multiple knowledge forms by their unique philosophies and identities. Also, the worldviews of different knowledge may affirm some unbridgeable differences. For example, dominant knowledge forms (e.g., Western science knowledge) sees the universe as something to be controlled and dominated while other knowledge systems (e.g., Indigenous and local cultural knowledge) speak of a search for peaceful co-existence with Nature. What all this points to is that it is important to acknowledge that in the intellectual and political project of affirming multiple knowledge the "normalization of difference" is distinct from the sheer rigid classification of 'absolute differences'.

The strength of Indigenous knowledge lies in their application to the lived realities of people. The relevance of Indigenous knowledge is that it speaks to the practical and mundane issues of social existence. In the face of entrenched hegemonic relations and global economic and ecological threat, knowledge is relevant only if it strengthens a people's capacity to live well. It 
is concerned first and foremost with questions of survival. It is knowledge rested in "the livelihoods of people rather than with abstract ideas and philosophies” (Agrawal, 1995: p. 422).

Unlike Western science knowledge Indigenous knowledge cannot be simply understood in terms of its utilitarian purposes. Its existence signals the power of intellectual agency of local peoples. It is symbolic (intellectually, politically and emotionally) in the projection to others that local peoples can and do know about themselves and their societies. It is about culture, identity and political survival. Culture and language are very central to "Indigenous" for without these the concept of "Indigenous" is meaningless. While today we must be careful to ascribe "Indigeneity" to all knowledge systems, we should also note that Indigenous knowledge are not homogenous. Such knowledge systems are demarcated by regional, class, ethnic, gender and religious differences, as well as specific socio-political interests in articulating such knowledge systems.

The urgency of affirming Indigenous knowledge systems for me rest of three fundamental projects of importance. First, is the realization of the continuing forms of colonization expressed in the imperializing and the peripheralization of knowledges, particularly in the Western academy (i.e., schools, colleges and universities) through official classroom pedagogies, curriculum, texts and knowledge representations. Second is the fact that is the need to develop resistance to knowledge colonization. For Indigenous scholars this calls for a political reclamation and revitalization our Indigeneity and histories. It also involves creating spaces for such multi-centric ways of knowing to flourish. Our politics of reclamation Indigenous knowledges must also be accompanied by a serious epistemological appraisal of our Indigenous knowledges. Third, is that we need to develop Indigenous knowledge constructs through the affirmation of an Indigenous science (see Le Grange, 2004, 2007; Solomon \& Aikenhead, 1994; Jegede, 1994), one that is validated on its own merit (i.e., focus on the understanding of the broad existential questions of life experiences rather than viewing science as simply a methodological tool). One approach is what I have called the creation of a trialectic space (see Dei, 2011c; Asabere-Ameyaw, Dei, \& Raheem, 2012). This space involves a dialogue among multiple parties a sort of “dialogic encounters" with an epistemic community. But more importantly, it is constituted as a space for learners to openly utilize the body, mind and spirit/soul interface in critical dialogues about their education. It is also a space that nurtures conversations that acknowledges the importance and implications of working with a knowledge base about society, culture, and nature nexus. Such spaces can only be created when we open our minds broadly to revision schooling and see schooling as place/site and opportunity to challenge dominant paradigms and academic reasoning.

\section{The Challenge of Contemporary Education}

Before focusing on local resource knowledge as source of educating and socializing young learners let me use the Ghanaian case to offer a brief overview of the context for West African education while addressing some direct and general questions. I should admit to the brevity of this discussion and the difficulty of speaking on broad terms given the complexity of the situation on the ground for most communities. But hope- fully a reader gets a general sense of the challenges and possibilities of West African education. Historically, education in the African context has been approached in terms of the contribution made fundamentally to national development. The education promoted primarily served the needs of the labor market/ the global economy, resulting in the marketization of education with the cultural trend towards a techno-fix approach to schooling, "standardization recipes" as (Lewin, 2008) notes. In emphasizing the goal of national integration and post-independence, "post-colonial” education in Africa has denied heterogeneity in local populations, as if difference itself was a problem. With this orientation, education has undoubtedly helped to create and maintain the glaring disparities and inequities, structured along lines of ethnicity, culture, language, religion, gender and class, which persist and grow. How research on African education acknowledge difference and diversity while, at the same time, highlighting commonalities, even among peoples with conflicting interests is critical. Ultimately, it is such an approach that can contribute to both national integration and social reconstruction.

Recently, there has been a resurgence of interest concerning "Education for All” (EFA) by the global community. Mundy (2008, p. 10) enthuses this resurgence is linked to two new developments. The first is "the emergence of fragile and deeply paradoxical consensus about international development among G8 governments. This consensus links development to democracy, good governance and human rights in a more extensive manner than ever before; while also strongly asserting the primacy of markets and capitalism. Education bridges these two sets of development ideals (see Mundy, 2008). Mundy (2008) continues that the second is "EFA has been fed by the burgeoning of transnational social movements that have used education as a core venue for advocating for global redistributive justice" (p. 10). Education is the preferred choice over other forms of social protection by the international community. So the new focus on basic education as a strategy for poverty reduction and alleviation. According to Mundy (2008) this ties in also with the emergence of "a transnationally organized global public that is critical of globalization and global economic inequalities, and that views the right to education as an important venue for expressing a commitment to redistributive justice on a global scale” (p. 11). Notwithstanding the above initiatives there is a continuing deterioration in access to education in the C21st.

Despite good intentions, Education for All (EFA) continues to be just a dream. So what accounts for the non-participation of children in primary school especially in sub-Saharan African countries with free primary education policy? How do we improve access to primary school among groups traditionally excluded from free primary education and assesses the impacts of such programs? By 2015, approximately 19 million children in sub-Saharan Africa will still be out of school if current trends continue (see African Population and Health Research Center, 2007). Who is at risk of being out of schooling and education regarding so-called sub-Saharan Africa? Despite some hard working initiatives to promote community welfare, we still know the emerging details of street children, child labourers, child soldiers, children from poor house-hold, children living in rural, remote and marginalized areas, and children orphaned by or infected with HIV and AIDS. How effective are free primary education policies, alternative education delivery, strategic 
interventions such as school feeding programs, and programs targeting orphaned and vulnerable children; programs aimed at improving educational quality such as improving the relevance of school curriculum, and supplementing teachers with trained volunteers, among others? Success in addressing problem of out-of-school children will depend on the following: clarity and consensus on policy issues, program objectives, and related interventions among all parties. There must be a concerted effort to target and reach the vulnerable population. But it is not just identifying populations for education. It is also addressing the content of such education. Perhaps education that goes back to the "roots" to cultivate and work with the teachings of local culture, social history and knowledge systems can be a good starting point to educate the contemporary African learner.

As noted in Dei (2011a) Indigenous education has been a prevalent aspect of pre-colonial times and today it still plays a role in the socialization of youth. Indigenous education has been significant in the socialization of the individual to become a productive member of society, where parents and the family were central figures shaping/educating the child. Indigenous form of education involved the entire community and was passed on from one generation to another, and in a manner that aids youth to practically and intellectually not only understand their natural environment, but also, their particular social function in society (see Fafunwa \& Aisiku, 1982; Sifuna, 1994). Traditional African education focuses on the molding of character and morality and the development of skills necessary for active participation in social life. In many West African rural communities traditional education is being transformed to offer knowledge, skills and capabilities to youth in many communities. One area for the infusion of Indigenous local cultural resource knowledge into schooling, education and socialization of youth is through proverbs, folktales and other forms of folkloric production (Boateng, 1990; Opoku, 1975, 1977).

\section{Case Study: Relevance of Local Knowledge}

Since 2007, I have been involved in a longitudinal research in Ghana, Nigeria and Kenya examining African proverbs and folktales for their pedagogic and instructional relevance in youth education, specifically in the areas of character and moral development of the young learner. The initial 2007 study was funded through a contract grant from the Ontario Literacy and Numeracy Secretariat (LNS) for a study on "Moral and Character Education in Ontario". The study has since been extended with Social Sciences and Humanities Research Council (SSHRC) funding for a longitudinal and more comprehensive study involving Ghana, Nigeria and Kenya focusing not only on the actual documentation of the proverbs, but also, on African Indigenous knowledge systems in general highlighting, the values of Indigenous stories, story forms, songs, folktales and riddles in youth education. The on-going study has extended the initial focus on ways of teaching discipline, moral and character education [from the perspectives of youth, teachers, school administrators, parents and communities] to examine the instructtional, pedagogic and communicative guidelines for using Indigenous African philosophies (conveyed in the documented proverbs, fables, folktales, myths, songs and story forms etc.) and how these can enhance learning for African and North American youth.
A major learning objective of the initial 2007 was to understand youth violence from the vantage point of learners and educators and how a local cultural resource base constitutes important knowledge for educating youth to not become involved in all forms of violence by the development of strong character, moral, and civic responsibilities. In fact, a specific pedagogic interest in African proverbs has been to examine how such local Indigenous knowings facilitate school teaching and learning about self, group, community, respect for Elders and authority, and the importance of identity and its connections to schooling and education. It is noted that West African schools [like schools in North America and elsewhere] continue to search for more effective ways of delivering education to a diverse group of learners. Local cultural knowledge, when used critically, can be important sources of information and/or be used as tools for educational delivery.

The overarching interest of the case study was guided by five learning objectives: 1) to examine the existing literature on what is known about the impact of teaching character/values education in general, and the implications for Canadian, North American and African schooling; 2) to understand teaching discipline, punishment and respect for authority from the perspectives of youth, teachers, school administrators, parents and communities; 3) to document past, current and long-term institutional approaches for dealing with youth [in]discipline and punishment, and respect for authority in educational settings; 4) to examine the instructional, pedagogic and communicative values and challenges in local Indigenous teachings (proverbs, fables, folktales, myths, etc.) about [in]discipline, and respect for self, peers and authority; and, 5) to suggest ways this study can enhance learning for African and North American youth by working with educators to develop learning and instructional materials and to develop strategies to implement character/ values education in Ontario schools.

The reporting on my case study deals strictly with the relevance of research information informing schooling and educational change in West Africa. But, to give a general overview, throughout the entire research period, 2007-09, at least a dozen focus group discussions had been organized together as workshop session with student-educators, field practitioners and educationists. There had been a total of over eighty-five individual interviews conducted with twenty-five educators; twenty Elders/parents and twenty-five students drawn from the local universities, secondary schools and community colleges, as well local communities in Ghana (an Nigeria (in the case of colleges and universities). The focus of the interviews was understanding the use and meanings of local proverbs and African Indigenous philosophies, as well as the instructional, pedagogic and communicative values and challenges in local teaching using proverbs, fables, folktales, myths, etc.) about self, community and group responsibilities, as well as respect for self, peers and authority. The research period has also been a time for me as Principal Investigator (PI) to network with Canadian educators and academic researchers on current directions in moral and character education research.

The epistemic saliency of local subjects is embedded in an awareness of the self and one's place within a collective. Knowing the self, community and culture is important in order to appreciate the challenges and how we respond. Since Indigeneity and issues of identity are powerfully linked, we cannot 
dismiss the power of Indigenous and local cultural knowledge. In fact, as Friedman (1992) also notes struggles over identity have serious implications when local peoples lose both their ontological and epistemological foundations. While culture may be negotiated, questions and issues of identity, history and the politics of affirming local knowledge are not negotiable for local peoples. Local knowledge contained in proverbs and parables are significant for expressing the intellectual agency of communities. Local cultural resource knowledge that allow for a critical reflection on past experiences and histories to respond to everyday problems and find solutions to problems is very relevant. Claiming such knowledge does not mean a recourse to a mythic or romanticised past. It is a realization that the past, a people's history and local cultural resource base have a role to play in the search for answers to daily concerns and problems.

\section{Study Findings}

In this section, I present some narratives from African educators that highlight ways of approaching the education and socialization of the contemporary young learner grounded in more critical ways of looking at local culture, traditions, values, norms and practices as dynamic forms of knowledge to be reclaimed for positive (solution-oriented) ends.

\section{Proverbs as Local Cultural Resource Knowings}

Anaafi [all names are pseudonyms] is currently a General Arts student in the senior high school in Ghana. At the time of the interview Anaafi was "in the second year going to the third year". When asked about proverbs and how he came to know about these cultural sayings:

I will say proverbs are wise sayings which are being said to us to learn from ... Well, I learnt them in school, at home, from my parents, my siblings and everybody. It is just the society and everywhere you go you hear people saying them. Even in movies and all that you hear people saying proverbs. [File 02: Text Units 9-16]

Proverbs are part of every day life and one learns them as one experiences life. When asked to be more specific how he came to know of proverbs, Anaafi replies:

...... in the process of teaching, some [teachers] use them. Basically, some of them use them in the process of teaching and some of the students even use them while we are in class so. [File 02: Text Units 42-46]

He acknowledges that the school system has been important site for educating on proverbs and would like to see more. Bafoah is also currently teaching core and elective mathematics at senior high school level. He insists proverbs do teach about responsibility. He argues that "proverbs [try] to instil a sense of responsibility into the students. There is a lot that he normally uses and almost always that he talks he uses a lot of proverbs". He reasons proverbs can be convenient for everyday conversations once a learner is well-versed in such cultural knowings. Additionally, Bafoah sees some differences in teaching about proverbs to students in secondary school as opposed to those in the elementary school, particularly in terms of pedagogical approach:

I think in the secondary school you will not have much problems because with the teenagers, a lot of them are intelligent. And they can reason through what you say. But at the lower forms, I think some of them ... in terms of maturity-they are not matured enough sometimes to understand some of these proverbs. Because some of the proverbs are heavy and they carry a lot of weight. So, I think at the lower level there will be that problem of breaking it down for them to understand.

There must be a different pedagogical approach to teaching proverbs in schools depending on the level the teacher is dealing with. With maturity comes a deeper appreciation of proverbs. Bafoah is asked to look at the school system in its entirely and the effectiveness of using proverbs in schools. When asked for specific suggestions as how to promote using proverbs for direct pedagogic and social relevance, Bafoah enthuses:

I would think eh ... it should be done subject based, you see. Like eh ... So, that at least ... eh ... It should be thought in such a way that teachers can use it as they teach. Because, sometimes for example, in English, I know that English ... there is a lot of opportunity there even in the stories that they use for their comprehension and ... I always remember this book that we read in secondary school; "Things fall Apart" has got a lot of proverbs in there. I remember those days we used to use some of these proverbs even in our daily lives at school. Yeah. So, I think that when it is subject based it will help a lot. [File 04: Text Units 213-237]

In other words proverbs cannot be integrated in all courses or classes. Certain subjects lend themselves more to integration of proverbs in classroom pedagogy. Kessie, a Science student at one of Ghana prominent Colleges in the Central Region claims to know a bit or two about local proverbs. When asked for some details of what he knows the educator responds:

I know proverbs are some short themes that are constructed or formed by our great ancestors which are handed over to the youth generation and helps us to know how to live. When one is living ... or because of a proverb one is able to live a very sincere life. Because when proverbs are made and you take a critical look at proverbs and you get to know the understanding you can see that proverbs are really very beneficial to us in our societies, in our communities, and even in the country as a whole. So, when you live with proverbs you will go far and it will help you in life.

Interviewer: That's good. Who did you learn proverbs from?

Proverbs ... mostly, I learned from my grandmother but it is unfortunate that she is no more. But for now, I learn proverbs from books. When I read books I try to get proverbs there and get the understanding. If I don't then I ask my dad or mum to get the understanding and use it in my life. [File 05: Text Units 13-28]

Faculty at a Nigerian University interviewed in a focus group discussion also see a need for African knowledge systems to be brought into the school system through the use of African proverbs. They see possibilities around this in terms of teaching about morals and character education. One educator was very insightful:

Female Educator: I think that most Africans; because amongst my people, speaking in proverbs shows mobility. Like we say in Africa the royal people or the royal families they don't talk. They talk in content and are very poetic in their talk. If you are not poetic, you understand, you are not supposed to be a proper African. Because I am not supposed to open my 
mouth wide to tell you everything I know. Just one single word, you understand? Everyone around will know. Suppose you are an ungrateful person, you understand and I want to tell my children not to be nice to you I will not ... Because we are great understand. ... if you are a fool you will ... Because my kids already know that this is what ... Any African who has grown up properly should be able to teach proverbs whether you are in the sciences or in archaeology or anything. Because I believe your parents will not talk to you from the day you grow, till the day you leave their house [File 13: Text Units 96-149].

The African learner who has been educated holistically will know about proverbs and their value in society as a powerful medium of communication. Patiah who is pursuing an M. Phil program in Human Rights at a local university, also elaborates on how educators can use proverbs to deal with some of the issues about discipline and violence in the school system:

For example, the elders have it that if you don't stay at home, for most of the time you will come and see that good things have taken place in your absence. In fearing that you should be at your doorstep to offer errands to your parents and to listen to good exhortations from your parents as well. If you are always on the street it doesn't augur well and you will one day find yourself in trouble. Another one, if you are a very good parent then you demonstrate or exhibit good for your children to emulate. So they continue telling us that a crab does not give birth to a fish. So whatever a parent does is likely to be emulated by the children. It is dangerous for example, to be getting drunk and then to be smoking and sending your children to concubines and others. It is a very bad example so these proverbs has taught us always to be careful of our ... even our use of language at home aha because children pick up these and they see whatever the parent does as a very good thing so such proverbs help us to be of wherever we find ourselves. [File 16: Text Units 91-119]

The message is clear. We cannot separate the learning of proverbs from Indigenous knowledge. Proverbs constitute part of local Indigenous knowledge systems. As attested to by one of her own colleagues, family head and Senior School Administrator of Academics, Nana Bodine, who is well-known for his knowledge of local proverbs such cultural knowings have powerful teachings that can be engaged by school teachers. Nana Bodine explains the uses of proverbs and why he uses proverbs in his own classroom teachings:

I use them to illustrate points. Now, when you are in a situation and you are able to use examples or illustrations it actually throws more light on it. And, the listener is firmly grounded in the know of the expression that you are giving the person. It is just like writing an essay or English composition or composition in any language and then you use examples or illustrations.

\section{[File 09: Text Units 19-41]}

Educators who utilise proverbs in their teaching enthuse that they reach the students more directly because it gets them to think and to use their analytical skills to solve problems. This may be a shift away form rote learning and regurgitation which has been the standard educational practices in most traditional African education contexts. I produce here a lengthy extract of responses of students interviewed in a focus group at a Nigerian College of Education as they share their understandings of the pedagogic and instructional importance of proverbs as cultural forms of knowing:
Female Student: It [proverbs] teaches morals.

\section{Interviewer: Can you speak a bit about that?}

Male Student: It teaches morals ... What the bible is talking about is that when your child is in your house; in your own presence; you rebuke him immediately and not say don't cover him and say I love him let me not say anything about it. That is not what the bible is saying. It says that you should correct him immediately in that act while he is doing it in your presence. Not in your absence. Proverbs ... train up a child because if you do not train up the child it is your fault that you did not train up the child. I don't know if any of you have heard the story? The mother was leaving the son to steal and every time he will steal money, then when he was caught outside being a robber, he was sentenced to death by hanging so before they hang him he said please I want to talk to my mum. When they called the mum, he removed her ears so that was her own punishment and he told the mum that "Mummy ... you did not train me”. So if a parent fails to train a child he or she is going to receive the repercussion later. [File 12: Text Units 636-656]

Female Student: What I see about proverbs is that proverbs is good because in this our Nigeria, the Yoruba, we believe in proverbs; anything that happens they speak up proverbs. In any situation, even you can use proverbs to punish. My mum that is why I cherish my mum. If she wants to tell me something she will use proverbs. I will sit down and think on it and ask "what does my mum mean"? You know, through that I will be able to or at times I will think about that proverb I will go out, I will reach out to people and ask them to please tell me the meaning of that proverb. If they tell me and if I get the message ... for that proverb then I will be able to apply it to my personal. [File 12: Text Units 661-687]

Female Student: I think everybody should apply proverbs, you know. I believe in my culture. I am a Yoruba. As our parents use proverbs, let's cultivate the habit of using proverbs.

Male Student: It should be on individual basis.

Female Student: I think the issue of proverbs and moral education; I think we all need to sit down and then we need to review our curriculum because there are some things that are not supposed to be added to our curriculum that are added. So they need to like sociology ... has long ... to teach morals and some other things about morals. So I think that one should come. And I think the issue of proverbs like we did in Nigerian education in the first semester. And in Nigerian education, teaching is about traditional education. There are some things about proverbs we are short off so I think there is the need. We just need to review our curriculum to suit us to cover those lapses. [File 12: Text Units: 714-737]

In the above discussion the students are stressing the moral education as well as socialization component of proverbs. They point to their instructional relevance in the homes, schools and other social settings. Fiifi, an Arts Design instructor in a Ghanaian college strongly believes proverbs have something to teach especially in instilling in youth a deep sense of moral discipline, probity and accountability:

With proverbs for instance, in teaching, now you may teach something which students may seem not to understand. But as soon as you introduce a bit of the proverb, whatever you have in our society, as soon as you put it there clear it tends to tell the student this is what the teacher means. Now, proverbs more or less are not profane words or let's say they are unique on 
their own. As soon as you put it there; you say it; people who understand will understand. And, there is no need to use words which are ruthless. So I think the proverbs; it has so many links with teaching. It helps even understanding, in some cases you want to tell a student-a particular student who is misbehaving in class; you want to tell the student something but if you go all the way talking a lot, you may end up insulting the student. But rather when you use the proverb straight away the student himself will reason quickly and say no, what I am doing is wrong that is why the teacher used this proverb. I think they are good. [File 15: Text Units 123-166]

As argued in Dei (2011a) education is about creating a whole person as a member of a collective. Proverbs offer cultural expressions of moral behaviour that is approved and sanctioned by the wider community. Proverbs regulate moral conduct, something vital to any learner.

\section{The Question of Language and Interrogating Culture}

To understand these proverbs and apply them in school teachings and classroom learning, it requires that both the learner and teacher become adept in the local Indigenous languages through which these proverbs are conveyed. Many educators have attempted to rephrase local proverbs in the English language and through that process a great deal is lost. An awareness of this 'lost in translation' is itself critical to emphasize why school ought to teach Indigenous language if proverbs are to be incorporated in school curriculum and instructional pedagogies. Similar cautions must also exercised in the whole area of understanding local/Indigenous cultures through the reclaiming of positive traditional cultural values. In a focus group discussion with final year student teachers specializing in Social Studies at the University of Education in Ghana, the students highlight respect for the Elderly, authority and school leadership as critical for moulding one's character and perserance. They point to cultural sanctions that can be applied in local communities to help cultivate in youth a sense of respect, discipline and responsibility to themselves, peers and authority figures. While is it debatable the effectiveness of some tradional sanctions and modes of enforcing discipline such as the use of the whip [cane it is important that we acknowledge the power of such sanctions in the socialization of youth. When asked specifically about the place of culture in schooling the following conversation ensured:

Interviewer: So how do we bring culture back in education or in school?

Student: All of us agree that our culture has been gone and we have integrated ... but we have forgotten one question. There are some aspects of the culture which was very bad and was very inhuman like the "female genital mutilation", ... Trokosi ... and other things which has gone. So as for that I think it is good. But there are some too which we could have retained but those one too are gone. Now looking at our culture as maybe when an older person comes in a bus you stand up and greet; I think that if the bus could have been partitioned.

Interviewer: That's the thing about no culture is immune to criticism. Every culture should be interrogated but the point you are making is a very important because there is the tendency to throw away ... about indigenous culture and just adopt ... So on the question about how do you bring back into the schools?
Student: I said that formerly they had something in school called culture studies. This in particular teaches about culture in the Ghanaian society and teaches both the good aspect and the bad and tells to show the bad and tells us maintain the good aspect but as time goes on culture studies has been taken away from the syllabus and has been replaced by other European ... (What do you call it) which we are being forced to learn. Because they said the world has become a global village and by so doing we neglect our own culture, so the generations coming forth, their minds are being polluted with the Western European style so they don't normally conform again to that part of the society that we are in. By so doing our culture is lost because it is the youthful generation that replaces the older generation. So until we are able to find that part of culture of our society and inculcate it in the curriculum, from the junior stages so that we can have people to teach and bring resource people from the society to really give examples, then if we do that then it means that we can bring our culture. [File 20: Text Units 1443-1513]

The students are lamenting about "lost culture". They also recognize that there are sites of empowerment as well as disempowerment in local cultures and cultural traditions. The students do not bring an unquestioned faith to the reclamation of culture. Every culture is dynamic and culture moves with the times. Their call to "bring back local culture" is grounded in a form believe that some aspects of traditional cultures have been helpful in socializing learners into responsible adults. No particular culture is an island unto itself. Cultures influence each other but one cannot discard their culture and traditions simply in favour of an alien culture. What learners can be assisted to do is to integrate values and ideas that have proven to work effectively in the socialization and education of youth in their own culture and cultural practices. The critical teaching of culture and cultural studies may be a good starting point.

Respect and culture can be context-bound. They are both part of the socialization process for youth. Socializing a learner is also teaching about respecting oneself, peers and authority. Lasi who attends the School of Ghana Languages and currently has a diploma in Akan reflected on questions of the school curriculum. When asked about the relevance of local cultural knowings and the curriculum, he offers some ideas that point to his views of teaching respect in schools:

Ah well, [local cultural knowings] like proverbs are normally not said in a vacuum. So we say "asem mba ye a ye nbu be." "Ye ndae a ye nso dae." [literally one cannot claim to have dreamt without sleeping] So, if you want to actually teach proverbs and you are good at it you do not necessarily line up a long list of proverbs; copy them on the blackboard or whatever and teach the children. You teach them in context. As you teach let's say grammar, as you teach reading you come across the proverbs then you deal with it and because it is in content the students will know the meaning better than when you have just put them there and then ... [File 22: Text Units 271-283]

Teaching respect and local culture is integrated practice. If one knows about their local culture and its values such knowledge cannot be separated from everyday educational practice. Such knowledge is grounded in everything one does. Local cultural knowings can be infused in school/classroom teachings as educators go about their everyday teaching. If socialization and education is to proceed the way African communities have 
impacted knowledge then it will be seen that local cultural knowings are infused in the vary processes of knowledge production, validation and dissemination.

On the relevance of gender and gender values in such discussions on schooling, culture and society final year social studies student teachers at the local University of Education in Ghana noted issues of gender bias, disparity and the absence of critical gender analysis in school curriculum:

Student: It is also very common ... especially seeing the female being highly marginalized in terms of curriculum in the performance of leadership roles. That is the topic on which I am writing on now. You see them as being sidelined when it comes to the performance of leadership roles in the classroom. Always women are somewhere and that trend has continued.

Student: When you get out to the field in politics; in all the executive sectors of the economy. We find men throughout. At times too most of them are being ridiculed and the few ones who will like to fight boot to boot with their men counterparts are nicknamed devil, witches and whatnots. I went somewhere and the lady was a carpenter roofing and thousand and one people were gathered looking at her and some calling her names. "Beyiefoo wei" [witches] and what nots ... all nasty names.

Student: It all boils down to the values. In our society it is said that even if the woman buys a gun it is the man who is supposed to keep it. It boils down to what the society perceives the woman to be. [File 20: Text Units 755-776]

In reclaiming culture the place of gender in society must be taken serious to interrogate social and political structures that marginalize women in society. Schools contribute to the problem by the lack any critical focus on gender issues to allow learners complete grasp of the complexity of social interactions. If culture is to claimed then the sites of empowerment as well as disempowerment for certain groups (e.g., women, children and religious, ethnic and sexual minorities) must also be exposed and addressed.

\section{Discussion}

For critical educators the question of what knowledge we teach, and why we teach these knowings is as important as how we teach (see also Dei, 2011a). These questions relate in part to the social organization of knowledge in our schools, as well as a realignment the social settings through which education happens. As correctly noted by (Mundy, 2008), the "hierarchical nature of many African school systems, as inherited from the colonial era, further entrenched inequalities...[and more so]... administratively, African school systems tended to be organized in a top-down, centralized manner, with little room for participation or innovation” (p. 6). Thus, external political and institutional factors lay at the root of African educational crisis. Policy weaknesses as far as African education is concerned can be summarised as a reluctance to introduce necessary in-depth reforms; weak public administration and institutions, an aversion to the institutionalization of bureaucratic practices (see also Ward et al., 2003). There is usually a lack of clarity and consensus on policy issues, program objectives, and related interventions among all parties involved. No concerted effort is made to target and reach the most vulnerable population.

As noted in Dei (2011a) Berthelemy (2006) studies found that African countries pay, relatively little attention to primary education, to the benefit of secondary education concluded that there exist bias resulting from institutional characteristics of Africa, which are deeply-rooted in its history (in particular its post-colonial legacy), its demography and its geography. African cultural resource knowings, embedded in local proverbs, parables, fables, myths, mythologies and folklores hold some useful ideas for schooling and educational policy for African youth. This case study offers us a way to rethink schooling and education through knowledge production, effective and meaningful classroom pedagogy and instruction, informed by community cultural resource knowledge base. In documenting local proverbs, parables, fables, myths, mythologies, and folklore the educative interest lies in the pedagogic, instructional and communicative significance for African students. The research findings help inform debates about educational change. Educational change must work with local knowledge, start from what local communities know, how they use their knowledge base and how such knowledge offer poignant lessons for educating the contemporary learner to be a responsible citizen for member of community.

The successful integration of local cultural knowledge into schools teaching and curriculum will depend on how African schools promote indigenous languages and cultures. As already noted, the teaching of local indigenous language is key to the survival of indigenous knowledge systems. Curricular initiatives in schools must seek to promote the teaching of local languages to all students. The diversity of local languages is not an excuse not to teach local languages. There must be an active promotion of local languages in schools. Many times educators do not employ proverbs and local cultural knowings in schools because they themselves are not well-versed in these languages. Schools do not only need teachers trained to teach specifically in indigenous languages,. We must also ensure that there is staff professional development for all educators that takes the teaching and promotion of African Indigenous languages and cultural knowledges seriously (see Brock-Utne \& Skattum, 2009).

School curriculum must be expansive enough to integrate and work with local cultural knowledges. This may require that we have effectively curricular, instructional and pedagogical approaches that infuse local cultural knowings in the areas of science, mathematics, arts, literature and social studies. African schools must change the rigid curricular structures. This approach will mean educating with a transformed school curriculum that places learners [their histories, experiences, cultures and knowledges] at the centre of their education. This enables the learner to feel a sense of self worth, collective responsibility and ownership of the learning process. Schooling must highlight the centrality of culture to knowledge production (pedagogy) and emphasize the importance of reaffirming and reinforcing the myriad identities of learners. By working with the ideas of community, solidarity, social responsibility, mutual interdependence, and collective histories young learners and educators begin to value and appreciate each other as contributing to the education of all. The idea of "schooling as community" can ensure that students, parents, Elders and local communities all develop a sense of collective ownership of the schooling process. The idea of "community education" may be engaged to ensure a close relations and bonding between schools, parents, Elders, families and communities. Educators 
working with knowledges from and about the different cultures, histories, heritages and intellectual agencies of all learners and centering these experiences in learning provide a needed sense of learners' ownership, control and responsibility over their own education.

Contextualized learning is about grounding education in local practice and experience. Through this approach learners are able to grasp knowledge when fully anchored in everyday experience as well as local understandings of the workings of culture, society and Nature. When student are able to relate classroom teachings to their own lived experience or everyday social practice that can learn better. By grounding teachings in local contexts, environments learners can easily identity with education and the production of knowledge. In the area of local/ Indigenous knowledge young learners affirm how proverbs and story forms have impacted knowledge to them from Elders and adults. Educators who lace their teachings with such local knowledges make an impact of their students as these students are assisted to think through the import of the message being delivered and to relate it to everyday experience, including local culture and the surrounding environments. The nexus of local culture, society and nature constitute a body of knowledge that educators can utilize in school teachings to deliver important educational message.

\section{Acknowledgements}

Thanks to Marlon Simmons of the Department of Sociology and Equity Studies, Ontario Institute for Studies in Education of the University of Toronto (OISE/UT) for helping me address reviewers' comments on a draft of the paper. Many individuals have assisted in this longitudinal study research in Ghana, Nigeria and Canada. I would like to acknowledge the assistance of Dr. Meredith Lordan, Munya Kabba, Jaggiet Gill, Camille Logan, Rosina Agyepong, Paul Adjei, Dr. Anthony Kola-Olusanya all of OISE/UT who at various times worked as graduate researchers with me on various aspects of the project. I am forever grateful to Professor Kola Raheem and the staff of the Centre For School and Community Science and Technology Studies (SACOST), University of Education, Winneba, as well as Mr. Paul Akom, former Dean of Students at the University of Education at Winneba for their invaluable assistance on my research project. My Visiting Professor ship for the 2007-08 school year at SACOST and the University of Education in Winneba afforded me the opportunities to make contacts which ensured success for my study. Similarly, I am indebted to Mr. Tola Olujuwon and the Provost, faculty, staff and students of the Adeniran Ogunsanya College of Education, Otto/Ijanikin, Lagos State, Nigeria where I was a Visiting Scholar for a short period in the Fall of 2007. Also, many thanks to Messrs Ebenezer Aggrey, Alfred Agyarko, Isaac Owusu-Agyarko, Martin Duodo, Kwaku Nii, Stephen Asenso, and Dickson K. Darko, all who served as my local research assistants on various aspects of the project. My sincere gratitude goes to the many Ghanaian and Nigerian educators, students and parents who gave their time for the interviews during my fieldwork. The Social Sciences and Humanities Research Council of Canada (SSHRC) provided funding for this study.

\section{References}

Abdi, A., \& Alie, C. (Eds.) (2005). Issues in African education: Sociological perspectives. New York, NY: Palgrave Macmillan.

African Population and Health Research Center (2007). Strategies for Universalizing Primary Education in Sub-Saharan Africa. http://www.aphrc.org/documents/Policy\%20Brief-\%20Strategy\%20f or\%20Universalizing\%20Primary\%20education.pdf

Agrawal, A. (1995). Dismantling the divide between indigenous and scientific knowledge. Development and Change, 26, 413-439. doi:10.1111/j.1467-7660.1995.tb00560.x

Asabere-Ameyaw, A., Dei, G. J. S., \& Raheem, K. (2012). The question of indigenous science and science education: A look at the literature. In A. A. Asabere-Ameyaw, G. Dei, \& K. Raheem (Eds.), Contemporary issues in African science education. Rotterdam: Sense Publishers.

Bascom, W. (1965). The forms of folklore: Prose narratives. Journal of American Folklore, 78, 3-20. doi:10.2307/538099

Battiste, M. A., \& Henderson, J. Y. (Eds) (2000). Protecting indigenous knowledge and heritage: A global challenge. Saskatoon: Purich.

Berthelemy, J.-C. (2006). To what extent are African education policies pro-poor? Journal of African Economies, 15, 434-469. doi:10.1093/jae/eji032

Boateng, F. (1990). African traditional education: A tool for intergenerational communication. In M. K. Asante and K. W. Asante (Eds.), African culture: The rhythms of unity (pp. 109-122). Trenton: African World Press.

Brock-Utne, B. and Skattum, I. (Eds.) (2009). Language and education in Africa: A comparative and transdisciplinary analysis. Oxford: Cambridge University Press.

Dei, G. J. S. (1993). Indigenous african knowledge systems. Tropical Geography, 14, 28-41. doi:10.1111/j.1467-9493.1994.tb00222.x

Dei, G. J. S. (2011a). Integrating local cultural knowledge as education for young African learners. Canadian and International Education Journal, 40.

Dei, G. J. S. (2011b). Indigenous philosophies and critical education. New York, NY: Peter Lang Publishing.

Dei, G. J. S. (2011c). The lessons of indigenous philosophies for critical education. Keynote Address at the 4th Annual Conference on "Decolonizing the Spirit". Toronto: Ontario Institute for Studies in Education of the University of Toronto.

Dei, G. J. S., Hall, B., \& Rosenberg, D. G. (Eds) (2000). Indigenous knowledges in global contexts: Multiple readings of our world. Toronto: University of Toronto Press.

Fafunwa, A. B., \& Aisiku, J. (Eds.) (1982). Education in Africa: A comparative study. London/Boston: George Allen \& Unwin.

Friedman, J. (1992). The past in the future: History and the politics of identity. American Anthropologist, 94, 837-859. doi:10.1525/aa.1992.94.4.02a00040

Ginsburg, F. (1994). Embedded aesthetics: Creating discursive space for indigenous media. Cultural Anthropology, 9, 365-382. doi:10.1525/can.1994.9.3.02a00080

Jegede, O. (1994). African cultural perspectives and the teaching of science. In I. J. Solomon, \& G. Aikennhead, (Eds), STS education: International perspectives on reform (pp.120-130). New York, NY: Teachers College Press.

Kudadjie, J. N. (1996). Ga and dangme proverbs: For preaching and teaching. Accra: Asempa Publishers. URL (Retrieved on 20 May 2005) www.afriprov.org/ebooks/gadangme.htm

Le Grange, L. (2004). Western science and indigenous knowledge: Competing perspectives or complementary frameworks? South African Journal of Higher Education, 18, 82-91.

Le Grange, L. (2007). Integrating western and indigenous knowledge systems: The basis for effective science education in South Africa? International Review of Education, 53, 577-591. doi:10.1007/s11159-007-9056-x

Lewin, K. M. (2008). Strategies for sustainable financing of secondary education in sub-saharan Africa. Human Development Series World 
Bank Working Paper No. 136. Washington DC: World Bank.

Limón, J. (1991). Representation, ethnicity and precursory ethnography: Notes of a Native anthropologist. R. Fox and Fe. Santa (Eds), Recapturing anthropology (pp. 115-135). Santa Fe, NM: School of American Research.

Mundy, K. (2008). Global politics and local realities in the realization of the universal right to education. In S. Moor and R. Mitchell, (Eds.), Power, pedagogy and praxis: Social justice in the globalized classroom. London: Routledge Adult and Professional Education Series.

Opoku, K. A. (1975). Speak to the winds: Proverbs from Africa. New York, NY: Northrop, Lee \& Shepard Co.

Opoku, K. A. (1997). Hearing and keeping. Akan proverbs. Accra: Asempa Publishers.

Pachocinshi, R. (1996). Proverbs of Africa: Human nature in the Nigerian oral tradition: An exposition and analysis of 2600 proverbs from 64 peoples. London: Continuum International Publishing. http://www.paragonhouse.com/catalog/product_info.php?cPath=23_ 46\&products_id=155

Purcell, T. W. (1998). Indigenous knowledge and applied anthropology: Question of definition and direction. Human Organization, 57, 258272.

Roberts, M. B., Haami, R., Benton, T., Satterfield, M. L., Finucane, M. H., \& Manuka, H. (2004). Whakapapa as a Maori mental construct: Some implications for the debate over genetic modification of organisms. The Contemporary Pacific, 16, 1-28. doi:10.1353/cp.2004.0026

Semali, L. M., \& Kincheloe, J. L. (Eds.) (1999). What is indigenous knowledge? Voices from the academy. New York, NY: Falmer Press.

Sifuna, D. N. (1992). Diversifying the secondary school curriculum: The African experience. International Review of Education, 38, 5-20. doi:10.1007/BF01097941

Solomon, J., \& Aikennhead, G. (Eds.) (1994). STS education: International perspectives on Reform. New York, NY: Teachers College Press.

Tucker, V. (1999). The myth of development: A critique of eurocentric discourse. In R. Munck and D. O'Hearn (Eds.), Critical development theory: Contributions to the new paradigm (pp. 1-26). London: Zed Books.

Ward, M., Bourne, J., Alan, P., \& Mark, P. (2003). Why do education policies in East Africa fail? What's changing? Journal of Education, 30, $127-148$

Wolfgang, M., \& Alan, D. (1981). The wisdom of many: Essays on the proverb. New York, NY: Garland Publishing.

Yankah, K. (1989). The proverb in the content of Akan rhetoric: A theory proverb praxis. Bern, Frankfurt au Main: Peter Lang.

Yankah, K. (1995). Speaking for the chief: Okyeame and the politics of Akan oratory. Bloomington \& Indianapolis: Indiana University Press.

Yankah, K. (2004). Globalization and the African scholar. Legon: Faculty of Arts, University of Ghana. 